\title{
Central Weaving Institute, Banaras: A Cultural Encounter between the Native and the Modern Form of Instructional Practices
}

\author{
Prakrati Bhargava*
}

(Received 10 February 2016; revised 12 April 2016)

\begin{abstract}
Handloom weaving was the most widespread industry in colonial India, next only to agriculture. A century ago India was the prime centre for trade of fine textile products. However, under the colonial rule it gradually transformed into a market for cotton-textile goods imported from Manchester and Lancashire. This also brought about technological changes in various processes of handloom weaving industry reflecting not merely a technological shift, but a cultural encounter where recipient already possessed a native system of handloom weaving. The present paper will examine the introduction of institutional mechanism of weaving industry on modern lines. The establishment of Central Weaving Institute in the heartland of weaving artisans 'Banaras', in 1912 is indeed a glaring example to modernize the weaving methods of artisans in United Provinces. Major focus will however be made on technological change in handloom weaving industry, followed by mapping of the efforts made by various agencies viz. provincial government or voluntary organizations to adopt and adapt the changes in handloom weaving in colonial India. Finally it will stress on the institutionalization of modern form of Weaving School at Banaras which was named Central Weaving Institute.
\end{abstract}

Key words: Banaras, Central Weaving Institute, Colonial government, Cultural encounter, Handloom weaving, Technological change.

\section{INTRODUCTION}

Weaving was practiced in India since ages and was extensively spread across the length and breadth of the country. The technological changes had to encountere resistance which was taking place in a society driven by its own socio-economic and cultural practices. Headrick (1998) pointed out that the process of technology transfer takes place in two forms; first the geographic relocation and the other in the form of cultural diffusion. Geographic transfer is marked by relocation of equipment, methods and experts from one location to another, while cultural diffusion signifies transmission from one society to another; of knowledge, skills and attitudes related to specific processes.

The cultural diffusion of technology may encounters both resistance and support from the recipient society. Paul Bairoch distinguishes the forms of technology in the early and late stages of Industrial Revolution; machines and processes in the early stages of industrial revolution were simple which craftsman could understand, copy and improve, whereas by the late nineteenth century industrial technology was no longer within the reach of craftsman and needed the knowledge of engineering and science (Headrick, 1998, 11).

Cultural diffusion of technology demands a willingness to accept a change, a strong political cohesiveness and a common vision for future (Headrick, 1998). Technological change is mediated by an agent; if the agent is internal and within the community, the resistance would be

\footnotetext{
*Assistant Professor, School of Education, Central University of Himachal Pradesh, Shahpur, Kangra, Himachal Pradesh, Mob: 8894702337; Email: prakratifun@gmail.com.
} 
weak or negotiable, but, if the agent is external, it could be strongly resisted by the community's socio-economic, cultural and epistemic tradition. Handloom Weaving was quite an old industry in India dating back to five thousand and eight hundred years (Rao, 1973, p. 1), where it was not merely considered as a profession, rather the community's internal relationship evolved from the profession. The industry which had witnessed a radical development due to modern science and technology was none other than the handloom weaving industry. The paper attempts to unfold the transmission of modern technology through the introduction of formal instruction for weaving community in United Provinces (presently Uttar Pradesh and Uttarakhand) which already possessed apprenticeship form of instruction within a community. The formalization of weaving instruction, not only marked the transmission of knowledge, but, as argued by Raina and Habib, that legitimate knowledge form and redefined knowledge system became, a symbol of cultural achievement and an imperative for development pursuit in the early twentieth century (Raina and Habib, 2004, p. 120). This legitimatization of knowledge was exhibited by colonial empire by establishing Weaving Schools in the prominent weaving centres in United Provinces viz. Barabanki, Banaras, Bulandshahr, Almora, Agra and Sitapur. A detailed analysis of course, curriculum and pedagogy of Central Weaving Institute, Banaras had been undertaken, as Banaras was the most prominent centre for silk weaving, practiced by Julahas (Muslim weaving community), who were well-known for their fine artistic work around the world.

The persistence of handloom weaving industry in the early twentieth century was not merely an outcome of consumption pattern and intrinsic flexibility of labour intensive technologies, but also a response to a technological change. The change was not driven by the competition from the power looms, since the new tools and processes came nowhere near to bridging the productivity gap between these alternatives. The need to become more efficient in supplying the changing market needs seems to be a significant factor in adoption of new technologies. However, the diffusion of technology was not homogenous and remained confined to certain places, products and group of weavers. Many scholarly studies have brought out varied factors responsible for slow change in technology during this period. Tirthankar Roy points out that the technological intervention is varied in different parts of colonial India depending on the relative intrusion of modern industry, exposure to western education, the attitude of the artisan and availability of new technology (Roy, 2002, p. 508).

Varied factors were responsible for the continuity of weaving tradition in colonial India. Morris argues that market for cloth expanded in the late decades of nineteenth century which was responsible for expansion of handloom weaving (Morris, 1969). Contrary to this, Bagchi attributed this to the durability and artistic work of handloom which was preferred among average Indian villagers (Bagchi, 1972, p. 220). There was not a significant shift in the dresses of women; sāris and dupattā (an attire used by Indian women) still figured as dominant dress forms, whereas a gradual invasion of trousers and shirts among working class urban men was evident. Nevertheless, in United Provinces by the first decade of the twentieth century the market share for handloom was still one third in quantitative terms (by weight) (Chatterjee, 1908, p. 12). Roy argues that slow change and resistance to change was characteristic feature in Central India whereas, in western India there was readiness to change in production processes (Roy, 2002, p. 509). The technological diffusion is driven by large flourishing market that establishes economies of scale and reduction in transaction cost. Moreover, at the community level;if members were willing to learn and share knowledge, it promoted the spread of technology. 
Technology needed certain social linkages for its survival. The social linkages of artisans as a class with science and technology are defined in terms of their socio-economic behavior and prevailing technological practices. This linkage is reflected through the interests of artisans in new technology for generating surplus and community's interest in developing new technology for improving its methods (Qureshi, 1990, p.168).

The prime area of technological change in handloom weaving industry in early twentieth century was warping, sizing, weaving and dyeing. The complex process of Indian weaving was dependent on equipments that were crude in appearance for producing various range of cloth from coarse to fine silk fabric. The Europeans were routinely struck by this incongruity in native process (Roy, 2002, 512). The advent of fly shuttle looms in early twentieth century transformed the handloom weaving in India. However, the diffusion of fly shuttle among weavers was hampered by lack of capital and the form of cloth, i.e. fine or coarse (Roy, 2004, p. 80).The slow diffusion; in part may be attributed to the absence to or inadequacy of information system or the setting up of institutions for the dissemination of better technologies. The first organized efforts by the government for instruction in weaving was initiated with the establishment of Weaving Institute, Serampore in Bengal in 1908; an important trading town for Danish and British merchants. The institute imparted instruction for teachers in weaving schools, overseers and managers of hand weaving factories and also trained handloom weavers and their children. In 1917, it had 134 pupils. The pupil from this institute appeared for City and Guilds of
London Institute and performed fairly well. The institute was not merely imparting instruction in weaving technology, but also in modern textile machinery and processes (Weston, 1942, p. 122).

The United Provinces' government made its first sincere efforts for assisting handloom weaving in 1900 by conducting surveys in handicrafts with a half-hearted intention of reviving them. The only province which made some serious efforts in this direction was Madras Presidency, where Alfred Chatterton, Director of Industries, established the Department of Industries and held few exhibitions and competitions to popularize new looms. He recognized the importance of instruction in improved weaving technologies and started a school in weaving town of Salem, on the Serampore Model (Report of the Second Indian Industrial Conference, 1907, p. 563). The School was closed in 1909 by the orders of imperial government, ostensibly driven by financial stringency, but the idea of technical school for weavers' survived (Roy, 2002, p. 517).

The handloom weaving industry had also become most debatable in the Industrial Conferences that were organized in various provinces from 1905 onwards. In the Second Industrial Conference in 1906 at Calcutta, Raoji B. Patel, Minister, Agriculture and Industries of Baroda State, in his speech underscored the shortcomings of Indian weaving technology and also suggested the improvement in this technology consistent with the needs of the Indian weavers. The most important challenge faced by the Indian industry was hindrances in the transmission of improved weaving methods among the weaving community. He categorically stated that this could

\footnotetext{
Serampore is a place near to Calcutta in Bengal. It became eminent for the efficiency of weavers who used an improved native looms. Bengal government deputed Havell, Principal of Government School of Arts, Calcutta to investigate the methods of these weavers. He suggested for employing Serampore weavers as teachers for improvement and extension of looms throughout the province. As he weavers were unwilling to leave their place, Bengal government arranged for the teaching establishment at Serampore for instruction of weavers and carpenters in the use and construction of fly shuttle looms. In most cases two weavers and carpenters were sent from each district to be trained at Serampore.
} 
be overcome by establishing weaving schools, imparting object lessons and assisting them financially through cooperative or government efforts (Patel, 1907, p. 10).

Reflecting on the contemporary condition of weaving schools in India, Patel stated, "only few schools possessed well equipped weaving factory, and without such a factory attached to a school where all preparatory processes and weaving in various branches suited to local condition can be practically taught, benefit derived from such school will be very little indeed"(Patel, 1907, p. 10). It was quite evident that the transition in handloom weaving industry from household production to Kärkhāna (factory) production by the end of the nineteenth century, led to shift from family based apprenticeship form of training to waged labour form. Subsequently, formal schools were needed for instruction in weaving.

Banaras was considered the home of design work; weavers were dependent on ustāds (master artisan) and celās (disciple) for design. There were only six to seven families where this art of designing was confined. The designs were first drawn on paper; then the designer made out a model of it in cotton thread on small frames, thus for a new or fresh design a substantial amount had to be paid to the designer (Chatterjee, 1908, p. 43). There was an urge for at least one school of design for the training of prospective teachers and designers. Further, the link between trained weavers and village weavers could be established through 'object lessons' imparted by the former in the villages by performing work on improved looms more efficiently. However, the acceptance of the new processes was a complex phenomenon pervading social, cultural and economic factors of the community. Lack of capital was another concern that obstructed the weaver to experiment with new technology. This could be overcome if the landowners or rich merchants can establish improved looms with beaming machine, not as philanthropy but on installments, which would be paid back by the weaver when he would conveniently use these looms (Patel, 1907, p. 11). Thus, not merely the weaving schools were enough to convince the weavers for adopting new technology, rather more systematic efforts by the community and the government could facilitate technical change.

\section{Handloom Weaving Industry in United Provinces}

The handloom weaving industry was widely distributed throughout the United Provinces. There was no town and hardly a large village where a few Julāhas and Koris ${ }^{2}$ were not found plying their hereditary trade. The koris were the most depressed class than the Julāhas, and latter decline to associate with former. It will be necessary to start separate primary school for Koris. The coarser fabrics (known ordinarily as garha and gazi) made of yarn of counts lower than twenty were mostly woven by Koris in the western and central region of the province whereas the fine muslin and silk was predominantly woven by Julāhas confined to eastern districts of the province. The coarse cloth was produced in Muradabad, Agra, Ruhilkhand (Nagina, Najibabad, Dharmpur), Lucknow (Unao, Sitapur, Khirabad, Hardoi) divisions. In these divisions there were small pockets of Julāhas who were plying on their own looms and producing fine fabric like dorya (a thin stuff of loose texture requiring yarn of more than forty counts), dog (fine check) in Agra division, Muslin and Jāmdān̄̄ woven by Julāhas of Jais in Lucknow division and also in Faizabad. In the western district like Mau (Azamgarh) and Banaras Julāhas were the dominant weaving community and were producing fine muslin and silk respectively (Chaterjee, 1908).

\footnotetext{
2. Julāhas were weavers from the Muslim Community and Koris were lower caste Hindus who were engaged in weaving profession.
} 
There was no division of labour and yarn was purchased from dealers for manufacturing. The community relationships were closely knitted or we can say using Durkheim terminology these relationship were based on mechanical solidarity (Giddens, Anthony, 2009, p. 14). Saris, dhoti, pagri (turban) were manufactured by the weavers with coarse as well as fine fabric for local consumption. Dhoti and sari were generic men's and women's wear respectively (Roy, 2004, p. 66).

With the initial turbulence in the early decades of twentieth century, the industry regained its momentum after the end of First World War and the Swadeshi Movement (Sheth, N.R., 1979, p. M103). A committee appointed by the United Provinces Government in 1924 admitted that the handloom industry had ample opportunities in the province and underlined this by stating,

\begin{abstract}
.....this industry is widely distributed throughout the province and is the second only to the agriculture in importance. The census of 1911 showed a total population of weavers amounting to 951,672 of whom no less than 53 per cent were actually engaged in the weaving industry; as the census of 1921 it is true these figures were quite maintained, where the decreases recorded were very slight (Industries Department, 1924, p. 75).
\end{abstract}

The committee felt that the handloom industry should be developed as a cottage industry, either as a whole time or subsidiary occupation. This perception of the committee came out of the sustenance of this industry under the open challenge of modern cotton-textile industry and observed, 'the industry had satisfied strongly marked demand owing to the fact that village people generally preferred coarse cloth manufactured by hand to similar mill made articles, while in the production of fine and artistic goods it has easily held the market against the mills'(Industries Department, 1924,p. 75).
Though, the industry had sustained under the acute pressure of modern cotton-textile industry, but there was no sign of improvement in the condition of weavers. The commercialization of handloom weaving industry by the turn of the century had transformed the weaving industry wherein the household production had been shifted to Kārkhānā production. Consequently, shifting the family apprenticeship to wage and child labour. Thus the master weaver operating the loom had become an authority, not only for paid and bani ${ }^{3}$ worker, but also by monopolizing the supply of raw material and paying for the finished products on the piece-rate basis (Rai, 2011, p. 78).

The weaving community of Banaras was predominantly represented by Muslims. The education practices of this community were primarily oriented towards vocational training and ethical instruction (Kumar, 2000, p. 121). On the one hand, the vocational training of the child was started at the age of eight by sitting on the pit looms, on the other, ethical education emanated from religious scriptures. The introduction of modern education was perceived by the weavers as rushing towards naukari ('service' office job) that was making a man unfit for hereditary profession. The aversion of the weavers for even the very preliminary form of literary education obstructed their advancement and confined them to the unscrupulous cycle of mahajans (money-lender) and middle man (Kumar, 2000, p. 121). The prevailing attitude among weavers and other artisans held that any form of school education for few years would make their sons averse to hereditary occupations and will end up unemployed. A.C. Chaterjee in his Industrial inquiry of 1908 in United Provinces, while discussing the socio-economic condition of Banaras weaving community, pointed out that

\footnotetext{
3. Bani system was the system where ordinary weaver received raw material to manufacture cloth as well as design from the Grhasta (master weaver). Grhasta was the hierarchal head of the production process. He connected the producer and the marketing network by participating in both production and marketing processes see Rai, Santosh Kumar, 2011, p. 78
} 
the julāhas were very orthodox (perhaps bigoted) Muslims, and many of them objected to rendering their boys to school where all communities were represented. He also stressed upon the need of primary education for weavers that could raise the intellectual standard of the community. Chatterjee suggested that initially schools exclusively for Julāhas should be started, the parents could in such cases, be allowed to supplement the ordinary courses by lessons in the Quaran and the principle of the Islamic theology.

Moreover, on the occupational side the weavers believe that use of improved looms would ultimately affect their interest by cheapening the production. The weavers of plain $K \bar{a} s{ }^{\prime} \bar{l}$ silk ${ }^{4}$ of Banaras admitted that they did not desire the introduction of any imported hand-loom, thereby diminishing the earning of the individual weaver (Chatterjee, 1908, p. 16, 22). It was also observed that the wealthy weavers had discouraged the use of fly-shuttle at one of the weaving school in the United Provinces, as it threatened to make the poorer weavers independent of them. Similar observation was held by Chatterjee in United Provinces and expressed his views as follows,

This is one of the reasons why I am afraid handloom factories will have a very uphill struggle. Even the master-weavers of Tanda, who are the proprietors of small factories and carry on a fairly considerable business, labour under the impression that the use of improved looms would vitally affect their interests by cheapening production (Chatterjee, 1908, p. 23).

Thus the power relation within the community had also played a significant role in acceptance of new technology. Moreover, the delicacy and aesthetic which marked the uniqueness of the artisans could not be achieved by complete mechanization of the process.
The weavers had evolved their own ways of working and leisure. The production may be closely associated with demand from the market and the supply of raw material. Alfred Chatterton in Madras Presidency had also experienced the difficulty in motivating the weavers to produce more by using improved looms, he observed:

....the difficulty which had to be faced lie mainly
with weavers themselves .... The weavers object
to turning out in a day more cloth than they have
been accustomed to, and neither in Salem nor in
Madras have we ever been able to get them to make
full use of improved way of working (Chatterjee,
1908, 22).

In Banaras the weavers of plain Kāśi silk admitted that they did not desire the introduction of any improved handlooms because as it would adversely affect the earnings of individual weavers. Chatterjee underlined that the fear for improved technology was not merely an outcome of technological bias, rather an outcome of complex socio-cultural and economic factors that determined the forms of training and the market for their product. On the economic side, the mechanization of the weaving process had greatly affected the demand for hand woven cloth as the latter was more expensive and had accelerated the competition.

Thus it may be said that weaving practice in India had been institutionalized pervading into the socio-economic and political activities of the community. Veblen defined institutions as settled habits of thought common to the generality of men (Latsis, 2010, p. 603). Many institutions are by nature vestigial. This implies that many institutions are not prompt to respond the changing needs of the human beings, rather they are outgrowth of set of beliefs and practices that corresponds to the needs of technological

\footnotetext{
4. Plain Kāśsi silk was a stuff weaving of which was introduced in the last decade of the nineteenth century. It was durable and cheap, thus quite popular. The yarn for plain Käśi silk was supplied by a Bombay Firm and was imported from Italy for more detail see Chaterjee A.C. p. 44
} 
development and different material needs of the past (Latsis, 2010, p. 603). Mokyr in his case study of British and French economies had identified resistance during the industrial revolution. The resistance to innovation is identified as a central element governing the success of new inventions. Such resistance usually takes the form of nonmarket processes. It consists of vested interests, whose assets are jeopardized by new techniques, as well as by intellectuals who are opposed to new technology on principle (Mokyr, 1992, p. 325). The silk weavers in Banaras were organized in a hierarchal relationship whereby master weaver had the control over nature of production, credit and the marketing chain. Banaras Sari designing and manufacturing was a monopolistic trade in the hands of naksabandh and ordinary weaver could neither afford the design nor the raw material and thus was dependent on master weaver for yarn and money. However, at Azamgarh there was a large number of independent weavers producing cheap sāri and dupattās (generic women's wear in India). The independent weaver had more opportunity to innovate for changing market needs while in a hierarchal system as prevalent in Banaras silk weavers there was little scope for experimenting in new products (Rai, 2011, pp.76-78). Independence was defined as right of possession over the finished goods, a right that was exercised through sale to consumers directly or through merchant who bid highest. Contrary to this, dependent weaver may or may not retain the right to sell to other parties, if not satisfied with the terms (Roy, 1989). The possession of right on the end product also determined the flow of capital, which subsequently played a decisive role in determining the production process.

\section{Indian Weavers and Challenges to Technological Change}

At the turn of the century improvement in weaving technique of Indian weaver drew the attention of provincial government. Chatterjee found in his inquiry on Industries in United Provinces that Messrs Hattersley loom was successfully used in a small weaving factory at Kanpur managed by Allen Bros. Similarly Rai Bahadur Gulshain Bhwani Puri, a firm manager from Banaras had installed Japanese loom, one imported directly from Japan and another copied locally at a cost of Rs. 175. Thus he turned out excellent cloth, both cotton and Kāśî silk from this loom at half the cost as compared to production at local looms. Similarly, Triumph loom, invented by Captain Maxwell of Salvation Army, was though good, but too expensive to be afforded by ordinary weaver (Chaterjee, 1908, p. 24). Indian weavers were skeptical about using flying shuttle looms for producing fine cloth because owing to greater strain, only comparatively coarse yarn which will not readily snap can be used for warp. Clearing these doubts Chatterton pointed out,

\section{the fly shuttle looms, no matter what type, must be constructed to suit the work for which it is intended ........ and it is mainly owing to the neglect of this point that fly shuttle weaving has made so little real progress among the Indian weavers (Chatterton, 1908).}

In Salem Weaving Factory, Madras Presidency, the looms had successfully undertaken the work of higher counts between 60 s and 100s and produced fine cloth. Further, to demonstrate the comparative advantage of different types of looms a competition was organized in Madras Presidency, which established that there was great advantage in the use of fly shuttle for every variety of cloth i.e. fine or coarse, wide or narrow (Chatterton, 1908, p. 57). Therefore, adaptation of looms according to the needs of the Indian weaver and financial support to weavers became the determining factor in popularizing improved looms. The initial cost for switching over from one process to another viz. traditional looms to the modern one required a substantive capital investment, which could not be afforded by the poor weaver. 


\section{The Establishment of Weaving Schools in United Provinces}

No ideal looms or other appliances can be found to suit all kinds of weaving or in different climatic condition. It was not possible for a small school functioning at a local level to make elaborate investigations in the subject, nor can the owners of pioneer factories be expected to lay out much time or money over the solution of different problems connected with hand weaving and the preliminary processes. Thus a Central Experimental Weaving Station under Government was proposed to be established for undertaking investigations in improved looms for varied conditions and requirements of the province, together with modification that will probably be required in them to meet the local needs (Bhargava, 1968 p. 260). Further, the experimental institute was expected to ascertain which of the improvements in the preliminary processes can be adopted in these provinces (1) by weavers working at home (2) by small capitalists starting hand weaving factory. Another function of the institute was to impart training in the principle and practice of different branches of hand weaving for educated youth who wish to set up hand loom weaving factories in the province. Thus, research and training institute in the form of Central Weaving Station was approved by the Industrial Conference at Nainital in 1907 and was hoped that an institution will soon be established (Basu, 1991, p. 134). All these efforts were drops in an ocean to modernize the handloom weaving industry that could contest the import from the British cotton-textile industry.

Contrary to this centralize form of weaving institution, A.C. Chatterjee thought that the expenditure incurred in establishing small schools at some of the large weaving centres e.g. Azamgarh, Tanda, Muradabad, Jaunpur would be more effective and efficient in popularizing improved looms among the weaving caste. A weaver working on his own would be able to utilize the cheaper appliances while co-operative societies and small capitalists interested in starting hand-weaving factories would be benefitted by the training of number of artisans in the comparatively more expensive methods and appliances. These industrial schools would, moreover, be of very great value indirectly in raising the intellectual standard among weavers. Nevertheless, the Hewett Weaving School was established in Barabanki in 1907 through the efforts of Deputy Commissioner C.A. Sherring and philanthropy of Talukdars headed by the Raja of Jahangirabad. The instruction was imparted on the Salvation Army models of improved looms. Though the weavers were convinced of the superiority of the new looms over the country looms for the plain coarse cloth weaving, but the biggest obstacle in its adoption was the cost, which stood in the way of an individual weaver. Subsequently, by April 1908 three Demonstration Schools under Government auspices were started at Shahjahanpur, Muradabad and Tanda. At these schools fly shuttle loom of the Madras type and Serampur type (viz. fly shuttle slay with warping beam but without a take up motion fixed on the ordinary country loom) and the Salvation Army automatic loom were being taught and demonstrated (Chatterjee, 1908, p. 28).

Beside these small efforts no organized effort was made by the Government to promote capital investment in the improvement or installation of machines, and no systematic investigation was carried out for the suitability of fly shuttle looms catering to the needs of local weavers. Subsequently, some District and Peripatetic Weaving Schools were established in prominent handloom weaving centres of the province. District Weaving Schools were opened in Moradabad, Muzaffarnagar, Shahjahanpur, Sandila and Almora with some fly shuttle looms and weaving instructors (Industries Department, 1919, p. 174). Courses in Weaving and Knotting were imparted in these schools on modern machines of one year duration, but no stipend 
was given. The students have to arrange their own yarn for weaving in most of the schools, moreover no instruction was imparted on machine repair or improvement. The schools had to frequently restrict their instruction to only few pupils due to shortage of funds. The Indian weaver was hard pressed and it was obviously difficult under these circumstances to give up his daily wages, and join the school.

Meanwhile, due to the outbreak of First World War, the war needs compelled the government to utilize its resources to its maximum. Thus Muzaffarnagar Weaving School was turned into a small factory supplying goods to the Indian Munitions Board. Responding to the war demands, the instruction in school was adversely affected and thus in 1916 forty students passed from this school with partial training (Industries Department, 1919, p. 174). Moreover, in the absence of proper motivation and aid for obtaining supplies of machine accessories some weavers had reverted to old looms.

Nevertheless, the students who came out of these schools had significantly contributed in popularizing the fly shuttle looms. In a small village of Bahari, 10 miles from Muradabad, 30 fly shuttle looms had been installed and in the whole district the number reached to 70 . Only 15 students were trained by the school, rests of them were self-taught or taught by these students. Thus the people were receptive to technological change, if they were convinced that it would facilitate their business and the people from their own community effectively conveyed this. Apart from these fixed schools, Peripatetic Weaving Schools were opened in the prime centres of weaving. These were mobile weaving schools with one superintendent and few 'mistries' (machine mechanic) camping in a village for a day or week depending on how quickly local weavers received their message. Thus weaving schools were started in Etawah, Mau and Agra. Mau, which was a prominent weaving centre did not have a weaving school until 1917, when a Peripatetic weaving school with six looms was started, weavers of Mau after visiting the school, asked the instructor; if he would instruct them at their home, if they would buy the machine? The instructor readily accepted their proposal and trained the weavers at their home and thus within a year 30 fly shuttle came up. It is quite evident that weavers adopted the improved looms if they felt that it will readily enhance their production. The Mau weaver's preferred fly shuttle looms for producing dhotis for local market, which they had to give up, if they would not manufacture it at a marketable rate, now producing three dhotis per day on a good margin. Another interesting incident took place at Agra where some Koris were convinced when they participated in a competition between old looms and fly shuttle looms organized by the superintendent of Peripatetic School at Agra (Industries Department, 1919, p. 177).

\section{Government Central Weaving Institute, BanARAS}

The more formal and systematic attempt to institutionalize weaving instruction came up with the establishment of Central Weaving Institute at Banaras. Though, Nainital Conference (1907) had recommended the establishment of Experimental Institute for handloom weaving which could undertake research in weaving technology as well as impart instruction in improved weaving methods, itcould not get materialized until 1912. A Central Weaving Institute, Banaras came into being for implementation of above scheme. The school had three classes viz. Junior Class, an Artisan Class, and a Knitting class (Industries Department, 1919, p. 173). Knitting class was introduced in the School for supporting hosiery industry which had firmly established itself in the province. Hosiery products like socks and cotton under vests were preferred by urban middle class, these products were earlier imported from Japan.

By 1917, the school had 75 students on 
its roll. The students of this school also sat for the City and Guild examination held at Kanpur. In 1918, five students sat for the examination, three passed in first division and two in second. Most of the student who passed the junior course joined the District Weaving or Peripatetic Weaving schools as instructors or as managers in local weaving shed. The students passed out of artisan class were working in a local weaving shed. The students of the Knitting class were employed in the Knitting factories at various parts of the province (Industries Department, 1919, p. 173).

The local Julahhas showed resistance to join the school. The two year course was too long for Julāhas to give up their daily wages and join the course as they had to learn only the improved methods and tools. Although the school was not appreciated by the local Julāhas, it was attracting weaving community from other parts of the province from District Weaving Schools and the Peripatetic Weaving Schools. (Industries Department Proceedings, December, 1924, p.72)

Yarn for instruction was issued by the Central Supply Stores. The Stores was started at the institute in August 1916, with the object of supplying yarn and looms accessories to the district Weaving Schools and weavers selling the finished products to the institute. A system of piece work wage had been introduced and the students were paid wages when they returns the finished cloth to the stores.

The obstruction in the supply of various articles from western countries during the First World War had given an opportunity to manufacture the goods which were imported earlier for local markets. The school also undertook experiment in improving and adapting the fly shuttle looms under local conditions. They had produced a cheaper picker for looms costing 12 annas as compared to the imported one costing Rs. 2-4-0 per pair and thus reducing the cost of looms by one rupee, as no iron was used in the manufacture of the sley. Another advantage was that it easily throw shuttle across the sley and in consequence a much higher speed can be obtained without any extra effort on the part of the weaver. It was easily repaired by the village carpenter. Moreover Babu N.C. Dutt and Balmukund Prasad of the institute had succeeded in producing a shuttle box with six shuttles. Further experiments were made to reduce the weight and also the cost of fly shuttle looms (Industries Department, 1919, p. 173). These efforts were drop in ocean with the extant of vastness of weaving industry in the province. Moreover, the resources; whether physical or human,were inadequate in all weaving schools.

An inquiry Committee constituted in 1921 under the chairmanship of Khan Bahadur Shaikh Maqdul Husain, Registrar Cooperative Societies, United Provinces with six other members from various walks of life, but without any representation from the weaving community. With regard to the District Weaving School and Peripatetic Weaving Schools, the committee observed that the general aim and objective for which they were established have not been fully attained as they had not been effective in popularizing the fly shuttle to the extent that was hoped and had not sufficiently attracted hereditary weavers, for whose benefit they were primarily intended (Industries Department, 1924, p. 74). Further, the teaching staff of the schools was deficient in practical knowledge and accordingly failed to command the respect of local weavers. The schools had grossly undermined the marketing of goods from cottage industry, and thus the efforts to motivate the cottage industry to adopt improved methods of production were limited (Industries Department Proceedings, 1924, p. 74).

Regarding Government Central Weaving Institute, Banaras the committee observed that the institute had not been as successful as was expected, that students (especially non-weaving students) on leaving the class of the institute lacked competence to start their own weaving enterprise, and that a little successful experimental work 
had been carried out on comparative assessment of different kinds of looms. The institute in fact had largely failed to fulfill the experimentation that were reasonably entertained of it (Industries Department Proceedings, December 1924, p. 75). They also pointed out that the Central Supply Store had not justified its existence and had not been conducted on commercial lines, since orders given to them were above the market rate.

Thus the committee regarded that this industry has so much of potential to progress despite of competition from modern cotton-textile industry; the Central Weaving Institute should be dedicated for the modernization of weaving industry. Thus it condemned the courses of the institute which were started for imparting training for the power loom industry and recommended that all instruction in power loom should cease. The committee clearly defined the functions of the institute as to undertake experiment and research work for the benefit of the handloom weaving industry; to provide technical instruction in handloom weaving which will qualify students to take charge at weaving school and to work as managers and mistries in factories and to provide such practical instruction in improved methods of handloom weaving including, preparation, finishing, designing and dyeing and in hosiery making.

The committee reorganized the institute into three major sections viz. a Weaving Section, a Hosiery Section and a Experimental and Research Section. Weaving section was further sub divided into three classes: A senior class for superintendent and managers; junior class for instructors and mistries and an artisan class for both weavers and non-weavers (Industries Department, 1924, p. 77).

A strict entrance qualification was prescribed for each section. An entrance examination for the Senior Class, comprising questions on English, Arithmetic (of a standard corresponding to that of school leaving certificate examination) and vernacular. In the Artisan Class 75 per cent of the seats were reserved for hereditary weaving caste and non-weavers admitted only when weavers were not forthcoming. Raibahadu Munshi Ravi Nandan Prasad, however, appended a note of dissent on this recommendation and argued that no distinction should be made between weavers and non-weavers in respect of scholarship and admission to weaving schools (Industries Department Proceedings, December 1924, p. 77). However, Government did not fully accept the dissent note, as it perceived that accepting the dissent was undermining the majority opinion of the committee and Board of Industries, but, amended the reservation for the weaving class from three-fourth to two third.

The Hosiery class of the institute was divided into an 'ordinary class', requiring primary education as entrance qualification and an 'advanced class' for those who had passed the ordinary class. The institute also had research section which laid special emphasis on experimental and research work for weaving industry. The committee made no recommendation for the grant of any stipend to 'advanced class' who joined the institute for the improvement of their technique, however, the Director and Board of Industries, United Provinces advised that such stipend should be given and they should be of substantial amount as it is necessary to attract man who had to compromise with their wage. The provincial Government was in agreement with Director and Board of Industries and decided that a sum of Rs. 100 per month for 10 month to students of advanced artisan course and left the decision regarding number of stipend on the Advisory Committee of the Institute. No stipend was awarded in the Hosiery class. The committee recommended two stipend of Rs. 30 per month each tenable for 10 months to the first two students of the final year of the senior class, on condition that they consent to carry on research work under the principal. 
The recommendations of the committee appeared to be encouraging and promising for modernizing the weaving industry. However, in reality the institution did not establish an organic link with the weaving community of Banaras. The figures of 1924 clearly depicts the indifference of weaving community; out of the 46 students in the roll, 16 were weaver, and only 12 were receiving a scholarship of Rs. 6 per month, which was far below the rate as recommended by the inquiry committee. In the Junior Class which had 30 seats, only 21 students took admission in 1930 and were given stipend of Rs. 5 per month (Industries Department Proceedings, 1930, p. 123). In the Senior Class as already mentioned an entrance examination was conducted in English, Arithmetic and vernacular which also required Matriculation examination as minimum qualification, but it was too difficult for institute to find a student with such qualification, because those who were qualified were not much interested in this vocation and those who were ready to attend the institution did not fulfill the requisite qualification. Thus out of 20 applications received by the institute only ten were admitted, though they did not comply with the eligibility criteria, but were somewhat close to that i.e. two had failed in the matriculation exam and one could read up to Patna matriculation.
In the Hosiery class also a similar pattern was witnessed. The Inquiry Committee constituted in 1930 to examine the situation of industrialization and technical education in United Provinces was dissatisfied with the functioning of the institute. Khan Bahadur Khalil-ur-Rahman, who was associated with weaving profession pointed out that the improvement in the machines made by the institute had to be tested by the skilled artisan, thus the class for skilled artisan had to be developed at any cost. There was formerly a weaver quarter which imparted instruction at weavers place but was discontinued later on. It was observed that this was very successful to improve the skills of weavers as they were reluctant to join the school, but could be convinced through demonstration at their own working place (Industries Department Proceedings, 1930, p. 123).

Despite the efforts of the provincial government to attract weaving community to the school, the weavers had not turned up for the courses dedicated to them and, even which did not require any entrance qualification. The reluctance of weaving community to attend the weaving institute was not merely instructional but had deep seated social and cultural considerations.

Table 1 Various Courses at Government Central Weaving Institute, Banaras from 1930-31 to 1932-33: Report of the Industrial Reorganization Committee Government of United Provinces, 1934, Allahabad. p. 43 A

\begin{tabular}{|c|c|c|c|c|c|c|c|c|c|c|c|}
\hline \multirow[t]{3}{*}{ S.No. } & \multirow[t]{3}{*}{$\begin{array}{l}\text { Name of the } \\
\text { Institute }\end{array}$} & \multirow[t]{3}{*}{$\begin{array}{l}\text { Year of } \\
\text { establishment }\end{array}$} & \multicolumn{6}{|c|}{$\begin{array}{l}\text { Average number during the three years } \\
1930-31 \text { to } 1932-33\end{array}$} & \multicolumn{3}{|c|}{$\begin{array}{l}\text { Percentage of Employment } \\
\text { to the ex-students }\end{array}$} \\
\hline & & & \multicolumn{3}{|c|}{ Admission } & \multicolumn{3}{|c|}{ Passed } & \multirow[b]{2}{*}{$\begin{array}{l}\text { In } \\
\text { Indust } \\
\text { rial } \\
\text { Conce } \\
\text { rn (\%) }\end{array}$} & \multirow[b]{2}{*}{$\begin{array}{l}\text { In } \\
\text { own } \\
\text { busin } \\
\text { ess } \\
(\%)\end{array}$} & \multirow[b]{2}{*}{$\begin{array}{l}\text { Particu } \\
\text { lars } \\
\text { unkno } \\
\text { wn (\%) }\end{array}$} \\
\hline & & & $\begin{array}{l}\text { Artis } \\
\text { an }\end{array}$ & $\begin{array}{l}\text { Non } \\
- \\
\text { artis } \\
\text { an }\end{array}$ & $\begin{array}{l}\text { Tot } \\
\text { al }\end{array}$ & $\begin{array}{l}\text { Artis } \\
\text { an }\end{array}$ & $\begin{array}{l}\text { Non } \\
- \\
\text { artis } \\
\text { an }\end{array}$ & $\begin{array}{l}\text { Tota } \\
1\end{array}$ & & & \\
\hline 1 & $\begin{array}{l}\text { Central } \\
\text { Weaving } \\
\text { Institute } \\
\text { Banaras }\end{array}$ & 1912 & 17 & 95 & $\begin{array}{l}11 \\
2\end{array}$ & 11 & 44 & 55 & 42 & 25.5 & 20 \\
\hline
\end{tabular}


From Table 1 it is quite evident that a small number of artisan joined the institute as compared to the non-artisan, but the success rate of artisan was much higher (64.70\%) as compared to non-artisan (46.31\%). Moreover, most of the students who passed from the institute were absorbed in the pre-existing industries, rather than starting their own enterprise. Thus, merely imparting technical knowledge do not ensure entrepreneurship, rather a sound balance between social and economic factors have to be ascertained for effective infusion of new technology. Local networks are far more decisive for the success of entrepreneurship than the national and global contact because networks in the specific business environment are the best source for disseminating information and knowledge for those who have ventured for the first time. The artisan class had social capital to initiate or expand their enterprise, but the non-artisan class completely lacked the social linkages which were required to understand the internal process to initiate an enterprise. Moreover, imparting of skill has to be incentivized through financial assistance during the instruction and post-instruction to initiate their own enterprise. Nevertheless, participation of artisan as instructors plays a crucial role in trust building and competence.

\section{BiBLIOGRAPHY}

Bagchi, A.K. Private Investment in India 1900-39, Cambridge University Press, New York, 1972.

Basu, Aparna. The Indian Response to Scientific and Technical Education in Colonial Era, 1820-1920 in Kumar, Deepak. (Ed). Science and Empire Essays in Indian Context (1700-1947), Anamika Prakashan, Delhi, 1991.

Chaterjee, A.C. Notes on the Industries of the United Provinces, Allahabad, 1908.

Chatterton, A. Weaving Competition in Madras, Indian Trade Journal Vol. IX, No. 106, 1908.

Giddens, Anthony. Sociology, Wiley India Pvt. Ltd., New Delhi, 2009.

Government of United Provinces, Industries Department Proceedings, March 1919.

Government of United Provinces, Industries Department Proceedings, December 1924.
Government of United Provinces. Report of the Industrial Reorganization Committee, Allahabad, 1934.

Government of United Provinces, Industries Department Proceedings, August 1930.

Headrick, Daniel R. The Tentacles of Progress Technology Transfer in the Age of Imperialism 1850-1940, OUP, New York, 1998.

Kumar, Nita. Lessons from Schools the History of Education in Banaras, Sage Publication, Delhi, 2000.

Latsis, John. Veblen on the Machine Process and Technological Change, Cambridge Journal of Economies, 34.4 (2010): 601-615.

Mokyr, Joel. Technological Inertia in Economic History, The Journal of Economic History, 52.2, (1992):325-338.

Morris, M. D. et.al. Indian Economy in the Nineteenth Century a Symposium, Delhi, 1969.

Patel, B. Raoji. Handloom Weaving in India, Second Industrial Conference, 1907.

Qureshi, M.A. Social Linkages of Artisan with Technology Upgradation of Village Pottery Craft, Economic and Political Weekly, 25.13 (1990): 683-688.

Rai, Santosh Kumar. Becoming a Grihasta: Hierarchies of Work under Handloom Weaving in Early Twentieth Century United Provinces, in Rana Behal et.al. (eds.) Rethinking the Work: Global Historical and Sociological Perspective, Delhi, Tulika, 2011.

Raina, Dhruv and Habib, S. Irfan. Domesticating modern Science: A Social History of Science in Colonial India, Tulika Books, New Delhi, 2004.

Rao, AkurathiVenkateswara. Handloom Weaving Industry in India-A Study. National Cooperative Union of India. New Delhi. 1973.

Report of the Second Industrial Conference held at Calcutta on 29th and 31st December 1906, Calcutta, Mazumdar Press, 1907.

Roy, Tirthankar. Relation of Production on Handloom Weaving in the Mid 1930s. Economic and Political Weekly 24.40(1989):PE21-PE25+PE28PE34

Roy, Tirthankar. Acceptance of Innovation in Early Twentieth Century Indian Weaving, The Economic History Review, 55.3 (2002):507-532

Roy, Tirthankar. Traditional Industry in the Economy of Colonial India, Cambridge University Press, Cambridge, 2004.

Sharp, A. Progress of Education in India 1912-1917, Seventh Quinquennial Review, Vol.I, 1918.

Sheth, N.R. Industrial Man of India: Some Observations and Reflections, Economic and Political Weekly, 14.47 (1979): M103

Weston, A.T. Facilities for the Training of Artisan and Craftsman in India, Journal of Royal Society of Arts, 90.4605(1942):12 